\title{
VALORAR EL SÒL DE FORMA SOSTENIBLE
}

\section{Albert Alegret Burgués Esteve Cabré i Puig}

Departament de recerca i desenvolupament

CEIAM cabré alegret S.L.'

Consultoria, enginyeria, i arquitectura metropolitana.

Remissió Article: 21-01-2008

Remissió definitiva: 14-02-2008

Paraules Clau: valoració urbanística, reparcel·lació, sostenibilidad, expropiació, mètode residual dinàmic, sòl en transformació, àmbit de pertinença urbanística Pareto, Kaldor-Hicks, Rawls

Resum: Voldríem destinar aquesta reflexió a considerar el valor econòmic ${ }^{2}$ generacional del sòl, tenint en compte la seva diversa naturalesa, particularment la submissió a la ratlla ${ }^{3}$ urbanística, tot relativitzant la possibilitat d'establir un valor real segons la llei, tal i com sembla desprendre-s'hi de la nova Llei de Sòl ${ }^{4}$ 8/2007.

Des del convenciment que el sòl és matèria primera, suport de l'activitat urbana i de l'urbanisme, de la que som administradors ara i també per les futures generacions, entenem que presenta tres estats reals als que donar resposta des de la seva valoració: sòl rural $-e l$ camp-, el sòl per ésser transformat -normalment de camp a ciutat-, i el sòl urbanitzat -la ciutat-. La separació entre els estats del sòl la realitza l'urbanista amb el planejament i l'ordenació del territori, destacant el traçat de la ratlla urbanística.

Si més no la ratlla només és realment transformadora quan esdevé una unitat d'actuació. La figura de gestió per realitzar aquesta transformació de camp a ciutat és l'Institut reparcel/latori, mitjançant el qual s'executa la transposició de drets inicials -parcel-les agràries- en drets finals -finques urbanes-, en aplicació del règim estatutari de la propietat, i com a conseqüència del qual es materialitza el contracte social, obtenint el privat una part de les plusvàlues creades.

No obstant això, els sòls que queden fora de la ratlla transformadora o d'altres necessàries també per equipaments i infraestructures interurbanes, i que en el present estudi anomenarem zona de frontera ${ }^{5}$, es troben en situació de desequilibri respecte d'altres, per manca d'un sistema apropiat de valoració.

Proposaríem l'existència d'un règim de valoració urbanística específica per la zona de frontera, on quedessin inclosos els sòls situats a tocar de la ciutat feta i aquells que hagin de suportar infraestructures $\mathrm{i}$ equipaments exclosos dels àmbits de gestió. Tots aquests terrenys podrien ésser considerats en situació de disposició forçosa, siguin o no siguin delimitats.

\footnotetext{
${ }^{1}$ Els autors, Doctors Arquitectes, es poden contactar a http://cabrealegret.com/

${ }^{2}$ Veure la distinció entre valor econòmic i valor financer a Azqueta AZQUETA OYARZUN, Diego (1994): Valoración Económica de la Calidad Ambiental, ed. Mc. Graw Hill, Madrid.

${ }^{3}$ Entesa, com aquell traç de dibuix, que limita el dintre i el fora, la zona inclosa i la exclosa, la zona afecta y no afecta a la transformació urbana.

${ }^{4}$ de 10 de maig de 2007, publicada al BOE núm.128.

${ }^{5}$ Veure tesis CABRÉ I PUIG, Esteve "Límits al mètode de Comparança" (Desembre 2005), (Pàg. 44,45,138 ).
} 
La seva valoració es faria tenint en compte un període de retorn generacional. Els terrenys així classificats hauriem d'ésser inclosos en un àmbit de pertinença urbanística ${ }^{6}$ on hi quedarien garantits el règim estatutari de la propietat, l'equidistribució de beneficis i càrregues, així com el contracte social esqueien.

\section{Introducció}

Del sòl poden donar-se diferents definicions, segons la característica del mateix que es vulgui destacar. En tant que forma part de l'urbanisme, el sòl és la matèria prima a transformar, sobre la que intervenir i del que certes característiques naturals pròpies -orografia, geologia, vegetació, zoologia etc..- tant poden ésser destruïdes, incorporades, com preservades d'aquella transformació. També és l'element que genera, i alhora rep, riquesa. El factor que acaba patrimonialitzant a favor dels béns que pugui arribar a contenir i explotar els seus valors intrínsecs ${ }^{7}$ com ara la dimensió, situació, i els privilegis mediambientals existents com vistes, qualitat i diversitat biològica, etc..

També, el sòl com a matèria primera, tot i la seva limitació, pot ésser intercanviat -canvi de titular-, ja sigui per l'actual capacitat de generar rendes o per la capacitat futura de fer-ho; trobant-se sotmès a les lleis de l'economia actual, en el marc del qual hom pren les decisions de consumir o d'invertir. Els sòls tenen utilitats que poden ser tant privades com col-lectives. Per exemple, els rius, i en general tot el sistema hidràulic, son béns necessàriament col-lectius. La terra que dóna fruit és, normalment, privada.

El desenvolupament dels pobles i de la civilització (socialització amb i des de la llibertat) porta a la necessitat d'ordenar els béns privats i els béns collectius. No obstant la característica de privat $(0)$ o de collectiu (1), en el sentit de Casahuga ${ }^{8}$, no sempre es presenta com una característica pura (o 0,01 ): la pròpia escassetat del recurs "sòl" fa necessari encarregar a un ens collectiu independent (administració pública) la interacció (ja sigui separació, o intersecció, o fusió) d'aquell sòl destinat per satisfer necessitats privades d'aquell que ha de satisfer les necessitats col-lectives.

El projecte de ciutat -on es transformen els béns privats i es creen els béns col-lectius- és possible només si existeix un pacte social ${ }^{9}$ entre els agents privats i colllectius. Tot i així, d'urbanisme -competència de caràcter autonòmic a Espanya- que sempre condiciona l'oferta de béns (lloc, tipus e intensitat) mitjançant la classificació i qualificació, que implanta les infraestructures (via pactes entre administracions), i controla els temps d'inversió (via control administratiu), mai aconsegueix interferir en la formació dels preus dels béns privats. Això es deixa, no sense resignació ${ }^{10}$, a les lleis del mercat, confiant en la seva optimalitat.

La societat ha confiat en l'urbanisme la planificació, ordenació i gestió del territori (el sòl). L'aplicació de detall, però, sempre acaba de la mateixa manera: dibuixant una línia (o ratlla) que delimita, separant, els béns -espais- públics dels béns -espais- privats, i delimitant els espais privats entre ells. Simplificant, delimita el camp de la ciutat, allò que cal transformar

\footnotetext{
${ }^{6}$ Veure Centre d'Estudis Immobiliari, nota tècnica Tm010, de setembre de 2006. "Per a solucionar el problema, es fa necessari definir un Àmbit de Pertinença Urbanística (APU des d'ara), com aquell àmbit de gestió urbanística, en aquest cas "virtual", que garantiria la equidistribución de beneficis i càrregues per a aquest terreny, atès que ni té aprofitament lucratiu ni es troba en un àmbit de gestió urbanística.

${ }^{7}$ Veure Dr. ROCA CLADERA, Josep (1986): "Manual de Valoraciones Inmobiliarias", Editorial Ariel. Barcelona.. i tesi doctoral La externalización de los valores inmobiliarios: el caso de la Sagrada Familia (2001) ALEGRET I BURGUÉS, Alberto

${ }^{8}$ CASAHUGA, Antoni (1985) :"Fundamentos Normativos de la Acción y Organización Social", Editorial Ariel, Barcelona.

9 i no sense tensions per factors de tipus local, o de limitació de recursos, entre d'altres

${ }^{10}$ Veure a diferents autors d'economia -Casahuga, Pascual, Azqueta, etc... la relació de les imperfeccions del mercat o causes dels mercats imperfectes.
} 
d'allò que cal preservar. De fet, la ciutat nomes pot créixer a costa del camp. I en això rau una de les claus del problema: la delimitació (la ratlla) que l'urbanisme proposa és falsa, artificiosa e instrumental?, o pel contrari és veritable, útil i imprescindible?

La nova llei de sòl, parla precisament d'això. De la separació del tipus de sòl, segons l'estat físic en el que es troba, de la patrimonialització de les plusvàlues (amb forma de béns privats) segons el règim estatutari de la propietat, dels drets dels propietaris i de les indemnitzacions escaients, del règim de deures i drets en el procés urbanitzador, i de l'expropiació per l'incompliment de la funció social de la propietat. Tot i que reconeix que la capacitat d'establir les ralles concretes no és estatal, sinó autonòmica, el cert és que proposa una única ratlla per a tots els espanyols, la lineal que separa el contingut de la propietat entre una realitat d'ús rústic i una realitat d'ús urbà. De fet delimita el contingut de la propietat i del seu valor econòmic ${ }^{11}$.

Cal recordar que el contingut econòmic de la propietat ve definit bàsicament pel contingut econòmic de seves facultats (gaudir, usdefruitar i disposar) més o menys les externalitats generades. La qual cosa ens indica fins a quin punt el valor real depèn del planejament urbanístic donat que és aquest el que estableix el contingut econòmic potencial final ${ }^{12}$. Per això creiem que el contingut del valor ve fixat també per la competència autonòmica. No obstant, l'Estat és el que ha de definir els criteris d'equitat i equidistribució i el contingut de les cessions socials (zones verdes, aprofitament, etc... d'una mena de contracte social urbanístic), per a tot tipus de situació en el que es trobi el sòl, i que garanteixin tant la seguretat com la igualtat dels titulars arreu de l'Estat.

Per això trobem a faltar a la nova llei el reconeixement de la situació del sòl que de forma provisional és rural, però serà transformat en ciutat properament, o és urbanitzat, però serà reurbanitzat properament. Són els terrenys, que més endavant anomenarem sòls en situació de frontera, sotmesos a transformació degut a la gran velocitat de creixement de les ciutats. Tanta velocitat que ningú pot assegurar que cada generació generi els recursos suficients com per amortitzar les inversions de la generació anterior i seguint invertint per a les generacions futures ${ }^{13}$.

\section{Reparcel·lació}

Arriben així al sistema de gestió per excel/lència -la reparcel/lació ${ }^{14}{ }_{-}$. La reparcel/lació, sistema cabdal de l'urbanisme espanyol ${ }^{15}$, és des del punt de vista de l'economia i del dret, un mecanisme compensatori de justícia relativa, sense el qual la comunitat reparcel-latoria no podria atribuir justament els recursos productius $(€)$ ni la mercaderia transformada (el sòl). La comunitat reparcel-latoria no és ni més ni menys que aquells agents que queden compromesos per la delimitació -la comentada ratlla- que l'urbanisme hauria traçat tot complint la seva missió d'ordenació territorial. De fet la reparcel-lació és un cas concret en l'aplicació dels principis de l'economia social per la maximització del benestar social a la comunitat. La llei del màxim paretià, la de compensació de Kaldor-Hicks, i fins i tot la de Ralws acaben per complir-se de forma inexorable, en últim terme per la intervenció dels tribunals. La comunitat s'estableix sota

\footnotetext{
${ }_{11}^{11}$ Art. 20 a 27 de la llei 8/2007.

12 Potser fora escaient plantejar si la competència per dotar de contingut a la propietat no pot ésser una competència diferent de la competència urbanística, donat que és l'urbanisme el que estableix els components de valor. Només restaria de l'Estat la garantia de l'equitat.

${ }^{13} \mathrm{El}$ concepte generacional es substancial a la consideració del termini d'amortització de les infraestructures d'àmbit local, autonòmic i estatal.

${ }^{14}$ Entenem que els convenis de cooperació no són més que casos particulars on el número de propietaris tendeixen a la unitat, i la expropiació com cas particular quan les voluntats privades no garanteixen l'èxit del planejament. Així es demostra a innumerables sentències en els tribunals.

${ }^{15}$ Formulat per Idelfonso Cerdà per la gestió del Eixample. Veure CERDÀ, I. (1867): "Teoría general de la urbanización y aplicación de sus principios al Ensanche de Barcelona". I.E.F., Madrid, i recollit per la primera Ley del Ensanche de Poblaciones de 1867, i lleis successives -Lleis de sòl de 1956, 1976, 1990, 1998, 2007
} 
el principi del major i millor ús, dins de les regles de joc traçades per l'ordenament superior. Tots els partícips entren amb la condició que ningú perdrà; i diem encara més: donat que és segur que algú guanyi (si ningú guanyés no es faria la transformació) aquest ha d'ésser capaç de compensar als que perdin i encara seguir guanyant. I si això no resulta suficient per donar viabilitat a la transformació urbanística, es demanaran ${ }^{16}$ més sacrificis per tal de garantir que la resta de la societat no inclosa de forma expressa a la comunitat reparcel-latoria, surti guanyant també quelcom ${ }^{17}$. I com que parlem del benestar social l'estat ha de protegir-lo, regular-lo e impulsar-lo. La reparcel/lació, per tant, no és més que la materialització del contracte social urbanistic entre dos col/lectius.

Aquesta ratlla transformadora -la que permet la reparcel/lació, i que l'urbanista ha de dibuixar imperiosament, i que és necessàriament limitadora d'àmbits diferents (públic - privat, privat privat) és, en la seva forma i funció, completament necessària. Serveix per instrumentalitzar el procés de transformació real del sòl, per crear ciutat nova, tot garantint l'equidistribució dels beneficis i càrregues dins de la comunitat reparcel-latoria i d'aquesta amb la resta de la societat, aparentment maximitzant el benestar col-lectiu en l'àmbit social de referència.

\section{De qui és la plusvàlua?: col-lectiva o privada}

A ningú se li ha escapat que fins ara venim donant per fet que l'urbanisme genera plusvàlua, i que aquesta podria ésser titularitzada tant pel propietari del sòl inicial com per la collectivitat. Certament al llarg del nostre urbanisme així ha estat de forma majoritària. Particularment hom remet a la llei de sòl de $1956{ }^{18} \mathrm{com}$ la llei precursora de l'actual sistema. Ara bé, a ningú se li amaga, també, que podria qüestionar-se si la plusvàlua és tota collectiva o només ho és en part. També si la plusvàlua ve creada completament amb l'aprovació del planejament general o derivat, o si altrament es va generant a mesura que ens apropem al moment de la possible materialitat, amb l'aprovació definitiva del planejament derivat, del projecte de reparcel·lació, i de la urbanització.

La plusvàlua, en sentit estricte $i$ en referència a l'augment de valor de canvi, representa la diferència entre el cost complert per transformar un ecosistema territorial en altri, i els valors creats, mesurats en termes econòmics. Tant mateix, podem mesurar-la igual que es mesura el concepte de l'excedent total d'un projecte d'inversió ${ }^{19}$. És el valor creat, que la metodologia clàssica d'avaluació explica, en últim termini, mitjancem la taxa interna de rendiment -tir-. Val a dir que això ho fa a la formulació matemàtica base del mètode residual dinàmic ${ }^{20}$.

La discussió creiem que, a banda de la pròpia de la taxa a la que predeterminar la plusvàlua, ha de centrar-se en la titularitat de la plusvàlua, o amb més precisió, en els denominats drets de propietat (DDP) del sòl, a la terminologia econòmica clàssica. Amb sinceritat existeixen arguments a favor i en contra. García Bellido ${ }^{21}$ i els redactors de la nova llei de sòl aposten, perquè els DDP són inicialment de la collectivitat, sota la idea que és el planejament general que no la reparcel-lació- el que genera la plusvàlua. Per tant no l'aplicació literal de l'assignació dels DDP a favor de la col-lectivitat, ja des del pla general, implica que aquests DDP han d'ésser traspassats a altres titulars abans de materialitzar la reparcel-lació clàssica, doncs en cas contrari -que els DDP quedin titulats a favor de la col-lectivitat- atorgaria un monopoli absolut a aquesta: el propietari del sòl quedaria com a simple espectador, i amb un monopoli a

\footnotetext{
${ }^{16}$ Via els ratis socials de la llei de sòl i de la llei d'urbanisme o via convenis.

${ }^{17}$ Cessions d'aprofitaments, assumpció d'inversions col·lectives com la urbanització, etc...

18 virtut, García de Enterria, E., Bassols Coma, M., defecte García Bellido, J., Roca Cladera, J.N., Clusa Oriach, J., etc...

${ }^{19}$ veure PASQUAL, Joan (1999), "La Evaluación de Políticas y Proyectos: Criterios de valoración económicos y sociales", pàg. 129 i sgt. Editorial Icària .UAB, Barcelona

${ }^{20}$ veure ordre ministerial ECO/805/2003 de 03 de 27 de marzo de 2003

${ }^{21}$ GARCIA BELLIDO, Javier (2005) Revista CIUDAD y TERRITORIO n 143
} 
la matèria primera, segons diuen alguns economistes, l'eficiència i optimització del procés econòmic podria trobar-se en dubte. De fet és exactament el que planteja la nova llei de sòl al seu art. 24 , assignant el $10 \%$ de la plusvàlua generada com a compensació al propietari al que no és permès la seva participació a la reparcel·lació. 
Aparentment, i ens perdonareu l'atreviment, aquesta discussió pot deixar entreveure que les diferències són degudes als diferents models d'estat als que ens poguéssim referir: l'estat lliberal, o capitalista, en front de l'estat socialista amb economia de mercat. Al primer model l'estat és necessari pel funcionament de l'economia, regulant als privats com a titulars dels DDP, i substituint la iniciativa privada quan la rendibilitat no és assegurada, entre altres funcions. Al segon model l'estat atorga i distribueix els DDP, inicialment col-lectius, entre diferents agents: productors, consumidors, administració, etc.., a canvi d'una part dels beneficis -o plusvàlues creades-

No fa gaire un promotor conegut especialitzat en inversions immobiliàries a la Xina ens explicava que l'obtenció de la classificació i qualificació del sòl la donava directa i personalment el secretari general de la demarcació local del partit comunista, amb el qual negociava les compensacions que rebria l'estat xinès i, entre d'altres, la construcció dels habitatges nous per els actuals ocupants del territori -a la Xina no existeix la propietat privada-. És a dir, davant de l'inversor amb disposició d'invertir-hi a curt termini, l'estat -representat pel secretari general del PC- feia el planejament general -establia a on podia construir-se-, negociava el quàntum i garantia una reparcel-lació adequada per els titulars inicials -l'estat i els usuaris- fixant les inversions a fer pel privat a canvi del permís. A la pregunta obligada de si l'hi sortien els números em va contestar que havia d'anar amb molt de compte ja que el preu de venda venda del dret d'ús exclusiu durant 50 anys o ...- depenia de la capacitat econòmica dels treballadors xinesos de la localitat, i per tant de la bonança de l'economia local.

Un exemple que confirmaria que els preus de venda ${ }^{22}$ no depenen del cost de producció del sòl urbà. Que la creació de valor ve fixada pel planejament, però que només resulta rellevant si es materialitza a curt termini, i que ha d'existir una reparcel-lació que garanteixi l'efectivitat del contracte social entre privat i col-lectiu. I si tot això és així, l'existència de la plusvàlua és independent de la titularitat dels DDP. Altra qüestió que abordarem més endavant és la materialització de la plusvàlua en el procés de creació de valor de sòl.

La nostra conclusió fora que el model en el que de forma més clara pot conciliar-se l'existència del lliure mercat, la sobirania del col-lectiu envers el privat, la patrimonialització del titular de part de la plusvàlua, segons el règim estatutari de la propietat, i la patrimonialització del col-lectiu d'una part de la plusvàlua és el model de gestió per reparcel-lació, amb l'existència d'un contracte social urbanístic, contracte que cada realitat socioeconòmica i cultural ha de ferse a la seva mida.

\section{El contracte social urbanístic}

Anomenem contracte social urbanístic al conjunt de deures i drets que contrauen els privats amb les Administracions per poder desenvolupar un tros de ciutat nou, o bé per refer-ho. Simplificant, en tenim una part a la llei de sòl estatal (principalment art.16), també a les lleis autonòmiques, i quan pertoca en els convenis urbanístics amb els ajuntaments. Es tractaria de quantificar com la societat capitalitza la plusvàlua immobiliària. Els principals components a l'Estat espanyol serien:

> Cessió d'un percentatge d'aprofitament urbanístic lucratiu, típicament el 10\% (justificant-ho entre el $0 \%$ i el $20 \%$, novetat d'aquesta llei)

> Cessió dels sòls públics exigits per la legislació urbanitzats (sense cost per l'administració, novetat d'aquesta llei)

\footnotetext{
${ }^{22}$ Entre altres autors destaquem Mur-Clusa (2007) en el $n^{\circ} 2$ d'aquesta revista, on afirmen que "...los precios del suelo son precios derivados de los precios de la demanda. .... la vivienda no es cara porque lo sean los precios del suelo, sino al revés, como ya diagnosticó David Ricardo en el siglo XVIII".
} 
> Cessió gratuïta dels sòls destinats a equipaments, serveis tècnics, etc...

$>$ Compliment de determinades exigències de context físic, com realitzar connexions de serveis e infraestructures amb la resta de ciutat, etc...

> Compliment de determinades exigències de context social com realitzar un determinat número d'habitatges socials, o dotacions ${ }^{23}$.

Aquestes cessions o càrregues urbanístiques són totes a curt termini. La comunitat les rep al mateix moment en el que es generen els beneficis.

Però, ens és útil aquest sistema de gestió -reparcel-lació- per construir la ciutat que necessitem en el futur?. No ho creiem; el disseny de la ciutat del demà es confia a la resta de ratlles que delimiten l'actuació urbanística integral a llarg termini, que el més provable és que s'obtinguin amb el sistema d'expropiació forçosa. Davant de l'absència de figura de gestió comparable, els sòls que reservem pel futur no els incloem en cap àmbit en el que es pugui realitzat algun tipus de contracte social entre els propietaris, que de fet via expropiació acaben cedint els sòls a la comunitat futura que en gaudirà, i a la que ara representen els agents actuants.

Entenem que aquesta asimetria -els reparcel-lats avui i els que són expropiats per les necessitats futures- no fa igual a tots els titulars davant la llei: uns es sotmeten a transformació -inicialment voluntària- dins d'un àmbit reparcel/latori; els altres es sotmeten a transformació forçosa- dins d'un àmbit expropiatori. Amb la finalitat d'igualar-los caldria pensar-ne en un nou contracte social que hauria de respondre a les necessitats bàsiques de la generació futura amb la qual es buscaria una indemnització justa.

Per exemple, predefinint l'àmbit espacial i temporal al que referir el possible nou contracte social amb continguts com ara cessió d'un percentatge d'aprofitament territorial no local, o compliment de determinades exigències de context social: grans infraestructures, zones verdes, etc...; i tot amb un horitzó temporal a llarg termini. Això, no obstant, exigeix una definició del futur més concreta del que és tradició.

Si no creem, però, un sistema compensatori paral·lel a la reparcel/lació per l'adquisició avui dels sòls destinats a necessitats futures, hauríem de considerar un altre sistema econòmic semblant al que signifiquen els impostos a l'economia productiva i de consum (de la renda, de societats, de consum, els indirectes, etc...) garants de l'estat del benestar i la sostenibilitat del sistema: fora una resposta paral-lela i proporcional en l'àmbit de la inversió immobiliària urbanística als impostos a la producció. Podria existir uns fons socials urbanístics, uns comptes corrents al Banc d'Espanya per l'adquisició de sols lligats a sistemes no adscrits a àmbits lucratius? Potser no fora tan difícil de fer

\section{Valorar sosteniblement (I)}

Realment, les tècniques de valoració actuals ${ }^{24}$ permeten en termes generals, una correcta quantificació de valor de canvi tant en els sòls urbans i urbanitzats, com en els sòls rurals, i fins i tot els sòls inclosos dins de la ratlla reparcel-latoria, perquè es tracta de béns amb valor de canvi i pel consum present ${ }^{25}$. No obstant, el valor obtingut per les metodologies residuals pot ser considerat com el valor més alt possible, com s'analitzarà més endavant.

Però els sòls que, tractant-se d'ésser compensats avui, són destinats a necessitats futures sols en transformació, per a ferrocarrils, aeroports, ports, carreteres, grans àrees de protecció

\footnotetext{
${ }^{23}$ Particularment encertat les previsions del decret llei $1 / 2007$ de 16 d'octubre, sobre mesures urgents en matèria urbanística, del govern de la Generalitat de Catalunya

${ }^{24}$ mètode de comparança, mètode de cost, mètode d'actualització de rendes i residual

${ }^{25}$ Veure model VACO a ALEGRET BURGUÉS, Albert (2001), "Les Externalitats Immobiliàries: el cas de la Sagrada

Familia", pàg. 125 i sgt. Universitat Politècnica de Catalunya, Barcelona.
} 
mig ambiental, etc...- no sabem valorar-los, donada la comprensible aprehensió a especular amb el futur, més enllà de 1,03 anys.

Entenem, però, que el propietari que avui cedeix els terrenys a la comunitat pot considerar necessari una compensació mínima com la que rebria en el cas -hipotètic- que tots cedíssim avui els sòls per construir la nostra ciutat -lucrativa- que farem realitat en els pròxims 30 anys, hipòtesis que podria haver-hi segut aplicada en els imaginaris d'Utopia de Tomàs Moro?. ${ }^{26}$

Aquesta qüestió ens introdueix en la possibilitat de considerar convenient i justa una reparcel-lació intergeneracional -entre els nostres interessos i els interessos dels nostres fills $i$ nets-.

Si l'anterior és cert -la valoració avui dels drets futurs- implicaria el reconeixement d'una demanda futura certa -tan certa com per justificar pagar-la avui-. Podríem afirmar que si es tractés d'una demanda futura -30 anys- seria una demanda virtual perquè no és possible conèixer-la, perquè en tot cas fora una demanda estimada $i$, per tant, fora altament especulativa. Per tant aquesta forma de plantejar la compensació a la generació actual dels seus béns cedits per tal d'abastir les necessitats de les futures generacions no serviria, per arbitraria. No obstant, conclouríem que la generació actual no tindria cap dret a que la generació futura la compensés pel sacrifici de la cessió de sòls necessaris pel seu futur?.

Nosaltres creiem que si no és possible la reparcel-lació intergeneracional, mitjancen la utilització de la metodologia actuarial, pel fet de dubtar de la mateixa base metodològica -si la demanda és virtual, els valors són irreals- hauria de certificar-se una gran limitació de la pròpia metodologia actuarial. Altrament resulta obvi que no és el mateix anticipar la demanda dels pròxims 5 anys que dels pròxims 20. Malgrat tot, no hem de deixar d'aprofundir en la possibilitat. Per fer-ho cal, però, analitzar primer com, quan i quant de valor -la plusvàlua- es crea en el sí, de tota transformació urbanística -unitat d'actuació-.

\section{Anàlisi de la creació de valor de sòl}

Per fer la valoració d'un projecte d'inversió ${ }^{27}$ ja tenim l'instrument matemàtic adequat: la metodologia residual. La metodologia residual ${ }^{28}$-des d'ara sempre ens referirem a la dinàmicapermet fer estimacions del comportament dels valors, segons les rendibilitats exigides al llarg del temps per a un determinat àmbit de planejament derivat. És clar que els valors reals sempre són els que estableix el mercat; però no és menys cert que els que conformen el mercat -oferta $i$, sobre tot, demanda- fan servir el mateix mètode. $\mathrm{O}$ no? Però, no ens enganyem, aquesta tècnica ens pot donar el màxim valor, no el valor més probable, ni el valor socialment més just. El valor obtingut per la metodologia residual el podem nomenar valor màxim creat (VcS). És el màxim valor que el mercat estaria disposat a pagar. De fet, en època

\footnotetext{
${ }^{26}$ Veure MORO, Tomás (1518), "Utopía”, Traducida por Andrés Vázquez de Prada para Ediciones Rialp, 1989. Madrid.

${ }^{27}$ Que necessàriament ha d'estar fonamentat a una proposta concreta, sense la qual no es pot ésser rigorós amb la quantificació i qualificació tan dels ingressos com dels costos, veure PASQUAL, Joan (1999), "La Evaluación de Políticas y Proyectos: Criterios de valoración económicos y sociales", pàg. 212 i sgt. Editorial Icària .UAB, Barcelona

${ }^{28}$ Veure Centre d'Estudis Immobiliari, nota tècnica Tm017, d'octubre de 2006. "Realment hem de deixar de parlar de mètode residual estàtic i parlar de mètode residual, en la formulació estàtica o dinàmica. El mètode residual en la seva formulació estàtica és un cas particular del mètode residual que sempre té la formulació dinàmica. (...) L'experiència indica que quan els terminis mitjos de promoció se situen al voltant dels 12 a 18 mesos, els resultats de la formulació estàtica tendeixen a coincidir amb els de la formulació dinàmica."
} 
de cicle alcista ens consta ${ }^{29}$ que és el que s'arriba a pagar. Per contra, en època de crisis el valor més probable és inferior.

En els següents gràfics presentem la modelització del comportament del valor al llarg del temps dins d'una ratlla, dins d'una modelització d'Unitat d'Actuació Urbanística de $10 \mathrm{Ha}$ i sostre per uns 400 habitatges de $100 \mathrm{~m}^{2}$. La lineal groga (L1) representa el lloc geomètric del valor actualitzat dels fluxos econòmics de l'operació, amb taxa de descompte del $23 \%$.

Segons aquest model, entre l'any 10 i 12 el doble del valor de sòl rural (2 vegades $120.000 €$ ) gaire bé coincidiria amb el d'actualització dels fluxos immobiliaris $(\approx 240.000 €)^{30}$. Si la taxa hagués estat del $10 \%$ el creuament dels valors hagués estat entre l'any 30 i 40 aprox. I si del $100 \%$, entre l'any 6 i 7.

Figura 1: Valor reconegut (per la llei $8 / 07$ \& valor creat (v. màxim $\mathrm{m}$. dinàmic)

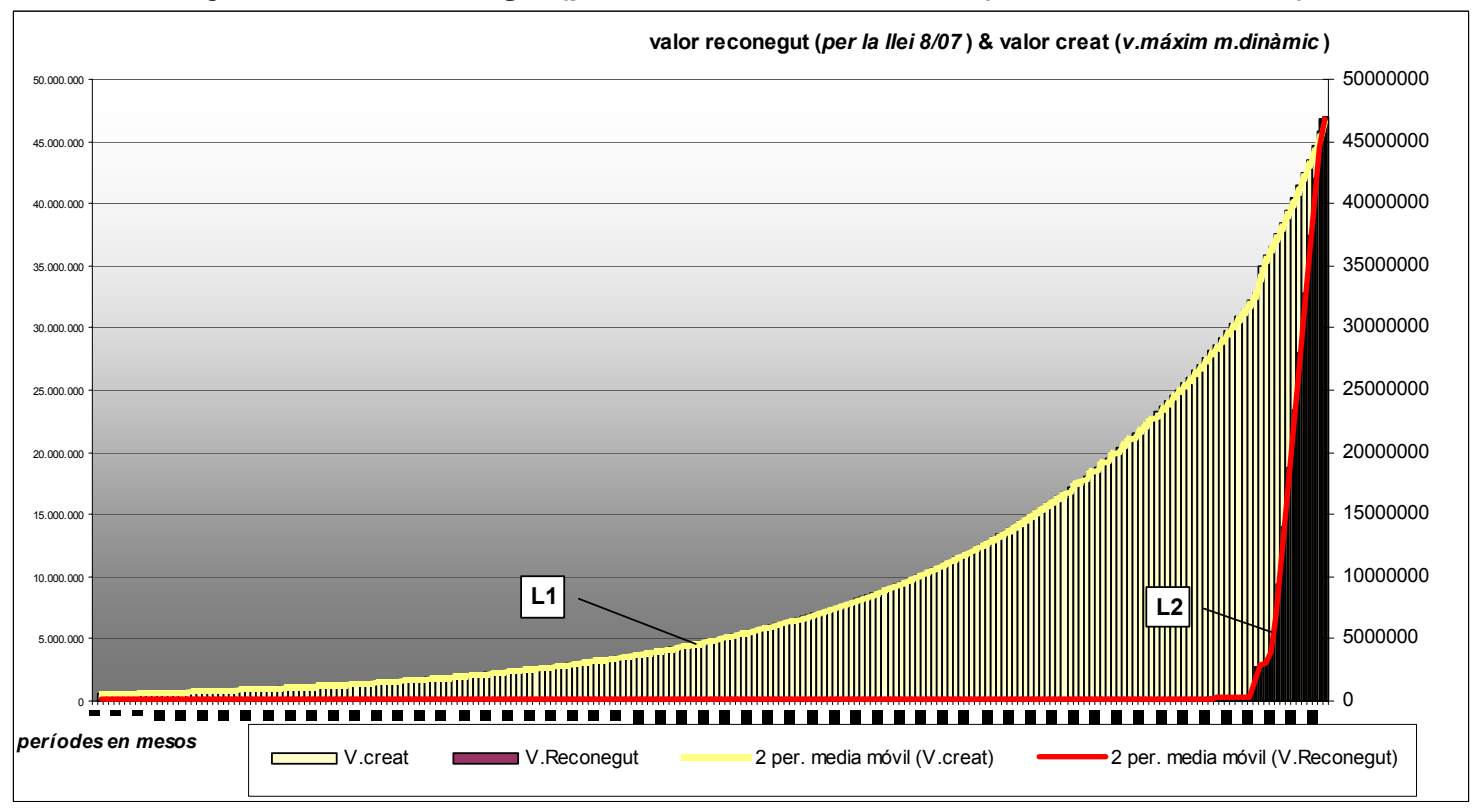

La llei 8/07 proposa un règim propi de reconeixement del valor patrimonialitzable mitjançant l'establiment de les indemnitzacions de les facultats de participar (art. 24) i de la facultat d'iniciativa de promoure (art 25), valors representats per la lineal vermella (L2). Només quan el sòl està urbanitzat i recepcionada l'urbanització, el seu valor és patrimonialitzable ${ }^{31}$. Abans d'aquest moment, sempre existeixen diferències entre el valor creat de sòl (VcS) obtingut mitjançant la metodologia residual i el valor reconegut per la llei (VpS) obtingut mitjançant la metodologia del cost ${ }^{32}$. La diferència entre el valor d'inversió efectivament produït i el valor creat és pot anomenar plusvàlua.

Òbviament, l'espai entre elles ( $L 1$ i $L 2$ ) suggereix algunes reflexions i no poques dubtes. Inicialment és l'espai de les plusvàlues, però, són patrimonialitzables?. Si la taxa d'actualització fos molt alta, la plusvàlua tendiria a desaparèixer? En depèn la plusvàlua de la taxa triada?. No, no en depèn, donat que a la formulació actuarial la modificació a l'alça de la taxa té el reflex

29 Els autors d'aquest article porten més de 20 anys de pràctica professional.

${ }^{30}$ Veure en ANNEX 1 el detall econòmic de la unitat d'actuació

${ }^{31}$ Amb l'excepció d'un mínim indemnitzable del \% de cessió (El 10\% del valor creat de sòl?).

${ }^{32}$ Entès com cost complert i augmentat per la taxa lliure de risc i la prima de risc. 
immediat en la disminució del valor actual net (el valor del sòl inicial o residual). Inversament passa si la taxa és baixa. Per tant, l'únic que fem és assignar la plusvàlua en més o en menys al productor o al propietari, no modificar-la.

Però, vegem-ne més. Considerem amb més detall -FIGURA 2- el període més proper al desenvolupament de la unitat d'actuació -per hipòtesis uns dos anys per gestionar la reparcel·lació i la urbanització, i uns 8 anys per l'aprovació definitiva del planejament derivat. Representem, com abans, la corba groga (L1) dels valors creats (de naturalesa immobiliària) i la corba vermella (L2) de valors reconeguts per la llei nova (el turonet representaria el valor mínim proposat per l'art. 24). Ara afegim un altre lineal (L3) que representi el lloc geomètric dels valors actualitzats que amb més probabilitat els promotors tancarien les operacions de compra de sòl a cada moment, obtinguda per aplicació del principi de prudència: no reconèixer la plusvàlua respectiva fins que, bé el sòl hi sigui delimitat (aprovació definitiva del planejament derivat) o bé estigui gestionat (amb l'aprovació definitiva del projecte de reparcel-lació), o bé estigui urbanitzat (amb la construcció de la urbanització). El càlcul que permet identificar el valor just abans de la aprovació definitiva (a.d.) del P.Parcial no por ésser més senzill: al valor actual net (L1) se'l dedueix el valor inicial del sòl -rural- i els costos invertits en la redacció etc.. de la figura de planejament. El mateix faríem amb el valor just abans de la a.d. del P. de Reparcel·lació.

Figura 2: Valor reconegut (per la llei $8 / 07 \&$ valor creat (v. màxim $\mathrm{m}$. dinàmic) \& valor més provable

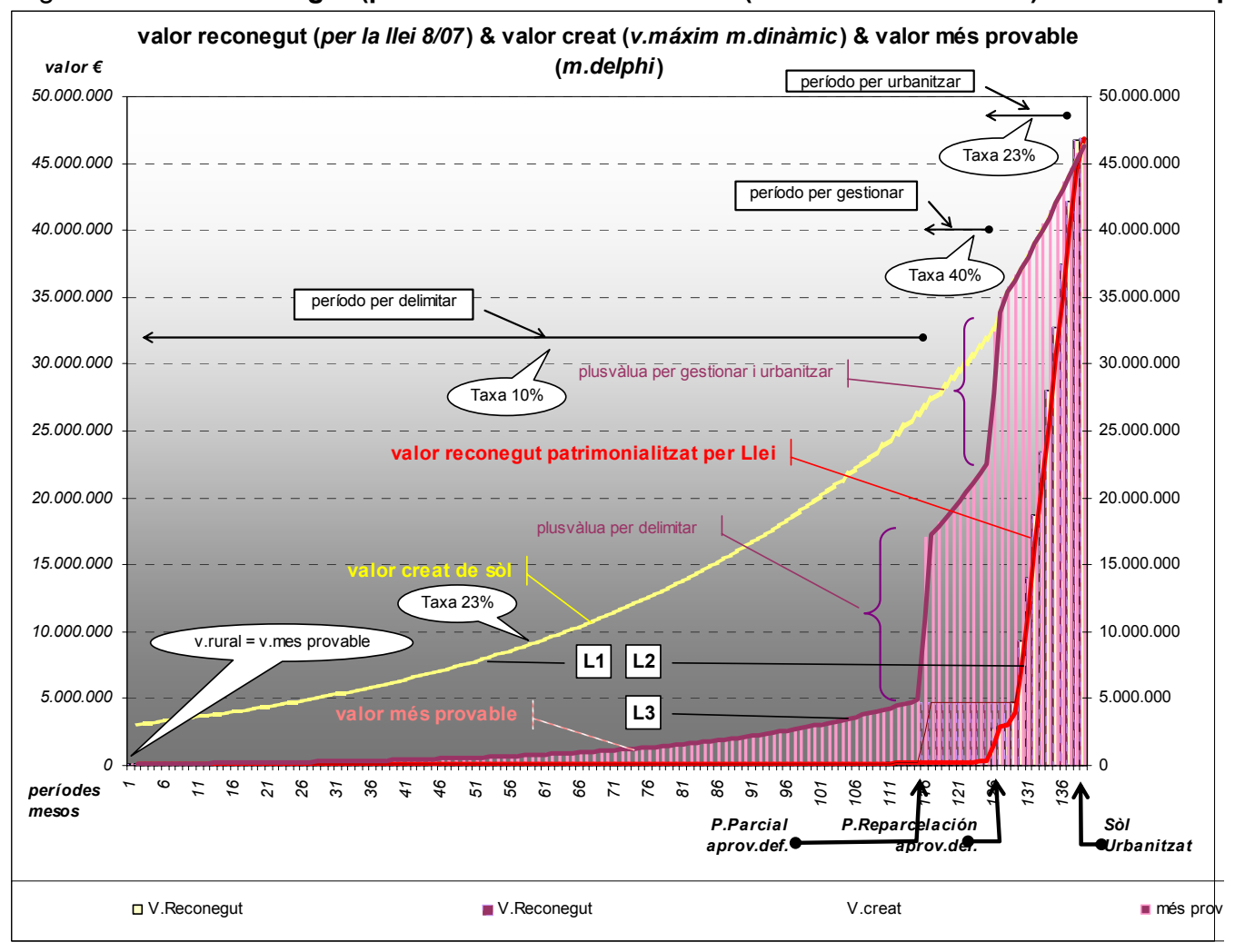


La FIGURA 3 (zoom de la FIGURA 2) ens apropa quelcom més al que passa a la promoció de sòl rural a sòl urbà, ${ }^{33}$ durant els períodes típics d'inversió, formats per els períodes necessaris per obtenir

1) la delimitació del sòl, o sigui amb el planejament derivat definitivament aprovat

2) el sòl gestionat definitivament, o sigui amb la reparcel-lació definitivament aprovada, i per últim,

3) el sòl urbanitzat, o sigui recepcionat per l'administració.

Val a dir, però, que per a millor visualitzar aquesta exposició hem triat unes taxes que permeten ressaltar els salts discontinus entre els períodes.

Figura 3: Valor reconegut (per la llei 8/07 \&valor creat (v. màxim m. dinàmic) \& valor més provable

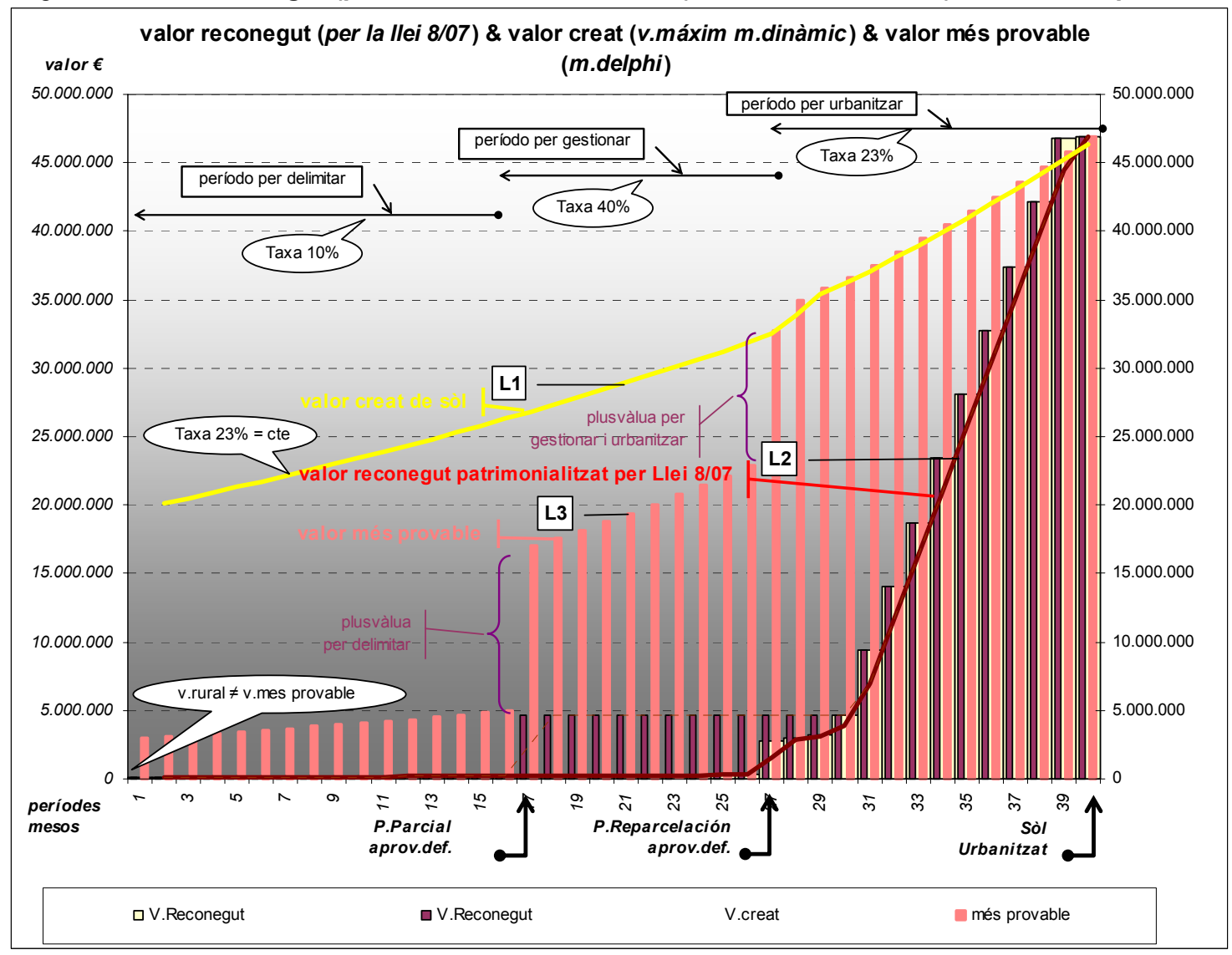

Podríem plantejar altres taxes diferents?. Certament. Ja hem dit que la taxa només serveix per distribuir el valor entre el productor i el propietari inicial, de forma que si la taxa és màxima anomenada TIR o taxa interna de rendiment- llavors el valor del sòl - el VAN o valor actual net - tendeix a zero, o sigui que quan menys pagui el productor pel sòl inicial, més gran és el seu benefici -s'apropia de gaire bé tota la plusvàlua-. Pel contrari, si la taxa tendeix al mínim, el

\footnotetext{
${ }^{33}$ Recordem algunes màximes de l'economia immobiliària enunciades pel professor José A. García-Durán, Catedràtic de la Universitat de Barcelona de Teoria Econòmica (Pamplona, conferencia el 14 de abril de 2000):

"1.- El precio de la vivienda viene determinado por la demanda del stok existente"

"2.- La demanda depende de la renta permanente y del tipo de interés real"

"3.- El precio de la vivienda determina el del suelo, y no al revés"
} 
valor del sòl serà màxim, és a dir la major part de la plusvàlua serà pel propietari. La figura següent mostra el mateix gràfic que la figura 3, però amb taxes molt altes: del $100 \%$ de taxa global, del $200 \%$ per període necessari per delimitar, del $120 \%$ per gestionar i $20 \%$ per urbanitzar. Amb aquest nou escenari, el creuament entre el valor rural i el valor creat (L1) succeeix

Figura 4: Valor reconegut (per la llei 8/07 \&valor creat (v. màxim m. dinàmic) \& valor més provable

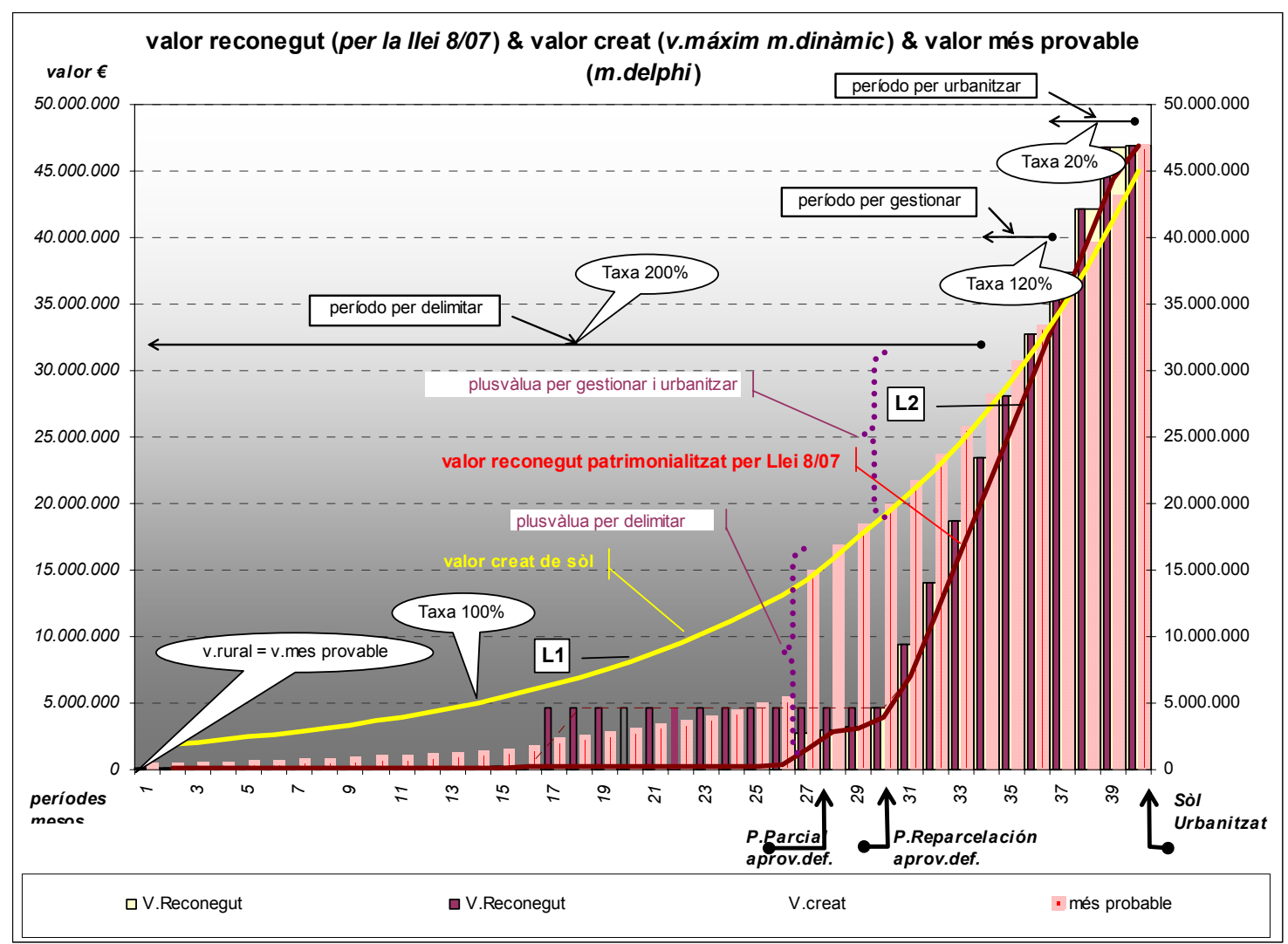

Aquestes consideracions no han d'amagar que quan parlem del productor ens estem referint a la figura del promotor - empresari, amb totes les limitacions que el dret d'iniciativa empresarial pot tenir per part de la col-lectivitat, figura que podria coincidir amb el mateix titular de sòl. Igualment, quan ens referim al propietari podem entendre que n'és el titular dels drets de propietat, també amb totes les limitacions que dit dret pot tenir per part de la col-lectivitat. I ja que la plusvàlua és constant, donat que depèn dels preus de la demanda agregada del producte final i no dels costos de producció, l'única discussió possible rau sobre a qui pertany. Si el model de funcionament de l'estat és tipus lliberal, es generarà un sistema impositiu sobre dita plusvàlua. Si no ho és, es funcionarà exactament igual però es dirà cessió per cànon o dret de concessió. En els dos sistemes el valor patrimonialitzat total com a suma del valor del propietari i el valor de la collectivitat tendirà a ser constant, donat que el productor -no propietari ni administració- només fabricarà i funcionarà amb beneficis industrials, no amb plusvàlues. Altra cosa fora que l'anomena productor esdevingués propietari mitjançant el sistema de permuta, li cedís qui li cedís; llavors obtindria beneficis de la plusvàlua, com l'altre copropietari. 
Però tornem a la proposta feta d'encadenar fites (delimitació, reparcel·lació i urbanització). Raonem que al final de cadascuna d'elles s'obtindran plusvàlues, perquè de fet, estem davant de tres projectes d'inversió diferent, que requereixen ésser tractats també de forma diferent. Això exigeix que la metodologia residual hagi d'ésser utilitzada en tres etapes, eliminant de cada una d'elles la plusvàlua no adquirida ${ }^{34}$. L'anterior versió de l'ordre Ministerial sobre normes de valoració hipotecària (OM 94 de 1 d'abril de 1994) ja establia per la fase d'urbanització que del valor del sòl acabat es deduïssin només els costos d'urbanització, posant com a condició que el projecte de reparcel-lació estigués aprovat definitivament (recordem que és el moment en el que les finques rústiques passen a finques urbanes al Registre de la Propietat). A la norma ECO/805/2003, pel contrari, no existeix cap indicació que la taxa del període hagi d'ésser variable, ni que s'impedís assignar valors hipotecaris com els de l'anomenada $L 1$-valor màxim creat-.

De fet, l'aplicació directa del mètode residual sense deduir les plusvàlues creades no garantides és la causa dels resultats irreals als quals es referia García Bellido a l'editorial de Ciudad y Territorio núm. 144, segons cita de Mur-Clusa a aquesta mateixa revista -núm.2-.

I, per acabar, de tot això, podem extreure alguna conclusió clara? Creiem que sí.

1) Que l'aplicació de la metodologia residual en la seva formulació dinàmica (inicialment la lineal groga, L1) per obtenir el Valor Actual Net exigeix (per transformar-se en la lineal L3) l'aplicació diferenciada (variable terminis i taxa) per els tres períodes "sòl delimitat" -fins planejament derivat amb aprovació definitiva (a.d.)-, "sòl gestionat" -fins reparcel·lació amb a. d. - i "sòl urbanitzat" -fins concloure la urbanització física-, eliminant la plusvàlua de cada període en el que no es consolidin els drets. Tot això si es pretén un resultat que reflecteixi el valor més probable ${ }^{35}$ enfront del valor més alt que és el que expressa el valor creat (m. residual dinàmic). És el reconeixement de tres tipus de riscos diferenciats que assignarien al productor més o menys part de la plusvàlua.

2) Que l'existència de l'espai entre la lineal vermella $(L 2)$ de valor reconegut per la llei de sòl $i$ la lineal rosada (L3) de valor més probable, en el període necessari per gestionar i urbanitzar, ens mostra la contradicció entre la valoració dels drets del titular del sòl si és expulsat de la comunitat reparcel·latoria ( $(\underline{L} 2)$ o no ho és ( $(\mathrm{L} 3)$. Aquesta contradicció ja ha estat apuntada per Mur-Clusa en el n 3 Vol.1 de la revista ACE.

A la llum del dit fins aquí, consideraríem que la proposta valorativa continguda a la nova llei de sòl esdevé tan allunyada respecte el valor real (valor creat més probable) com ho està la norma hipotecària, sempre que acceptem que la mesura del valor de sòl no la dona el mercat per comparació (rarament hi ha dades suficients) sinó que la dona l'aplicació de la metodologia residual.

Entenem que la derogació de l'apartat $1 \mathrm{r}$ de l'art.42. mitjançant la modificació de l'apartat $2 \mathrm{n}$ o sigui de la valoració de sòls, segons el criteri de valor real resulta imprescindible per a sostenir el sistema valoratiu proposat a la nova llei de sòl. Però si aquest apartat $2 \mathrm{n}$ fora impugnat $\mathrm{i}$ eliminat, el sistema valoratiu de la llei no es sostindria. Podria passar (hipotèticament, és clar) que mentre les accions d'una empresa immobiliària (que només promou sòl en transformació) es valorarien a preus de mercat (amb o sense llibertat de valoració d'actius) els seus propis actius (el sòl en transformació) haurien de ser valorats amb aquesta llei per sota del valor real.

\footnotetext{
${ }^{34}$ A la FIGURA 3 la plusvàlua final -per urbanitzar- s'ha sumat a la mitja -per gestionar.

${ }^{35}$ veure tesis Dr. CABRÈ I PUIG, Esteve (2005) Límits al mètode de Comparança, pàg.41
} 
També proposaríem la modificació de l'ordre ECO/805/2003 en el sentit ja comentat d'identificar els diferents projectes d'inversió i aplicar sobre d'ells la metodologia residual dinàmica amb diferents taxes per a cada projecte, procés que reflectiria els riscos reals.

Amb una òptica de valor sostenible, valorar com si el valor real fos el màxim valor és tant irreal com creure que el sòl a transformar val pel seu ús rural. Pagar el màxim valor pel futur és tan insostenible com n'és d'injust pagar avui menys que el que estaria disposat a pagar la generació futura. La solució al problema potser és introduir la consideració de sòl en situació frontera.

\section{Valorar sosteniblement (II)}

Aquesta situació de frontera vindria donada fonamentalment pel sòl delimitat no gestionat i el sòl per expropiar fora d'àmbits delimitats, i es trobessin en la mateixa situació de valor: disponibles per a ser incorporats per les futures generacions a la ciutat i les seves xarxes. Per tant, conceptualment-els terrenys- podran ésser forçats a participar en unes càrregues futures (realitzades ara pel servei futur) que han de quedar compensades (també ara pels beneficis futurs) de forma justa. No es tracta d'eliminar el principi expropiatori pel qual les plusvàlues futures no pertanyen al titular del sòl expropiat -pel que no serien indemnitzables pel futur sinó pel passat- sinó més aviat es tractaria de fer compatible l'eliminació del principi del major i millor ús consagrat per l'economia de mercat, amb la contribució que el titular del sòl fa a la comunitat, tot cedint-li els seus drets de desenvolupament urbanístic. Si així ho considerem, el valor resultant seria el mateix per a tots els expropiats amb independència del destí concret dels sòls al que es pensi destinar un cop expropiat, que de vegades poden ésser tan d'habitatge com infraestructures com zones verdes. La clau rau en que la zona de frontera es consideri un APU -àmbit de pertinença urbanística- de període una generació i usos lucratius referits ja a municipi, a comarques, a províncies, a Catalunya, a regions, a Espanya, a Europa, $\ldots$

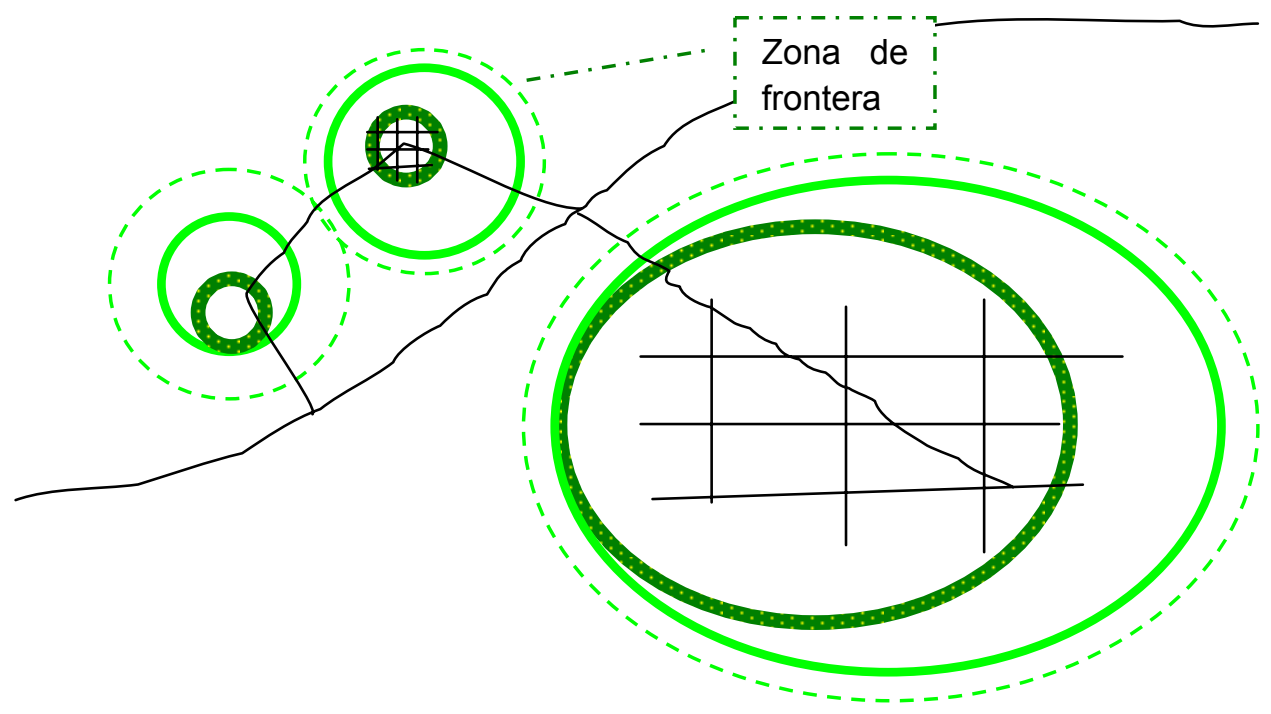

De fet i per les mateixes raons, en les àrees de transformacions urbanes, podria considerar-se que els drets a edificar dels propietaris urbans que no hagin estat materialitzats, són com una mena de drets amb data de caducitat, un dret a edificar no permanent. Front a un canvi d'ordenació -una decisió sempre col-lectiva sobre el futur destí d'aquell tros de ciutat- en el que 
dits drets són eliminats podria pensar-se a compensar la seva cessió forçosa de la mateixa forma que els sòls dits en zona frontera -donant al mot un caràcter més temporal-.

Haurem d'admetre que l'existència de la ciutat actual o futura no seria garantida sense el camp o sense la ciutat anterior. I que el que avui és ciutat, en generacions passades era camp -no ciutat-. No és just, doncs, que el que avui cedeix l'avi (l'actual generació) pel seu net (futures generacions) aquest li pagui un preu just?. Es tractaria de fer el que exactament estem fen com societat del benestar amb les pensions: solidaritat intergeneracional. Bé, estaríem d'acord en fer exactament el contrari del que proposem si l'objectiu del benestar comú fos compatible amb la facultat del propietari de gestionar lliurement el seu patrimoni -el sòl- amb les regles del lliure mercat, sotmès al principi del major i millor ús. Però això no és possible donada la natural tendència del mercat a obtenir el màxim benefici privat $i$ a curt termini, no social ni a llarg termini. Per tant resulta imperatiu que allò que no succeirà de forma lliure (invertir, produir, i cedir) donada la intrínseca incapacitat del mercat de transformar segons els principis del bé comú, hagi de ser un procés on l'equitat, l'equilibri i el justipreu hi siguin garantits per la comunitat.

En resum, que si tan veritat és que el valor del sòl rural és el valor actualitzat dels rendiments rurals, com que el valor del sòl urbà és el valor actualitzat dels rendiments econòmics urbans (o immobiliaris), passar d'una situació a l'altre generarà sempre plusvàlues importantíssimes com hem exposat anteriorment. El repartiment d'aquestes plusvàlues es dirimeix en el contracte social urbanístic, perfeccionat per la generació present en l'institut reparcel-latori. No podríem fer el mateix amb els sòls frontera, e incloure'ls en l'execució d'un contracte social mitjançant el qual podrien ser adquirits avui amb els beneficis futurs?. Podríem considerar-los inclosos en un àmbit de pertinença urbanística on es garanteix el just repartiment de beneficis i càrregues generacionals. Aquest àmbit podria assolir un valor residual en funció del futur creixement urbà, Aquests nous criteris demostrarien la seva validesa quan a un municipi petit li pertoqués cedir sòl per una gran infraestructura, per exemple Bescanó amb la MAT, o per implantar una presó, etc.... En els dos casos el valor just no és compensar pel valor, segons sigui de petita la població o el valor del petit hort, sinó en funció del valor que potencialment generarà la pròxima generació. $\mathrm{O}$ no?. També fora l'equivalent a no expropià i obligar a llogar el bé tota la vida, on el lloguer capitalitzat a determinada taxa ¿social? coincidís amb el valor ¿sostenible? d'expropiació.

Aquesta forma de veure els moviments de canvis de valor, segons la utilitat generacional dels mateixos, necessita un planejament que estableixi els sòls a expropiar (fora d'àmbits delimitats) amb horitzons superiors a 30 anys, els sòls a delimitar amb horitzons superiors a 10 anys, i els sòls a gestionar amb horitzons màxims de 5 anys. Aquest ritme es faria millor amb els moviments o cicles dels mercats tant el dels béns immobiliaris com dels laborals com dels de les grans infraestructures. De fet, és el mateix planejament urbanístic general el que ja incorpora aquestes previsions.

Deixeu-nos acabar, tot esgotant l'últim instant, manifestant que la necessitat de resoldre la valoració avui de les demandes futures, acompanya en paral-lel els esforços de destacats urbanistes nacionals -Bohigas O., Roger G., Sabate J., i molts altres - e internacionals -....enfocats a la introducció dels processos projectuals en la planificació territorial. Tots podríem trobar en la metodologia de l'anàlisi cost benefici un poderós aliat que copsés la importància de l'anàlisi per capes i propostes territorials semblants, tot ajudant a la seva quantificació: metodologia que pot esdevingué clau per valorar sosteniblement. 
ANNEX 1 (model d'unitat d'actuació)

La figurada unitat d'actuació presenta les següents característiques:

QUADRE 1

\begin{tabular}{|c|c|c|}
\hline Suelo Bruto & 10 & \\
\hline Edificabilidad B. & 0,40 & $\mathrm{~m}^{2} \mathrm{t} / \mathrm{m}^{2} \mathrm{~s}$ \\
\hline Cesión suelo & $50 \%$ & \\
\hline Cesión Techo & $10 \%$ & según ley \\
\hline Prima sin Riesgo & $5 \%$ & $0,42 \%$ \\
\hline Prima Riesgo & $18 \%$ & $1,50 \%$ \\
\hline Tasa descuento promoción & $23 \%$ & $1,92 \%$ \\
\hline Tasa de espera suelo rural, delimitándose & $10 \%$ & $0,83 \%$ \\
\hline Tasa de espera suelo delimitado, gestionándose & $40 \%$ & $3,33 \%$ \\
\hline Tasa de espera suelo gestionado, urbanizándose & $23 \%$ & $1,92 \%$ \\
\hline Tasa de espera suelo urbanizado, edificándose & $23 \%$ & $1,92 \%$ \\
\hline Valor Hectarea & $12.000 €$ & \\
\hline
\end{tabular}

També, les principals magnituds de valor a data d'avui, aplicant determinats ràtios de costos, serien

QUADRE $2^{36}$

\begin{tabular}{|c|c|c|c|c|c|c|}
\hline & $€ / m^{2}$ techo & & valor total & & pzo & origen \\
\hline concepto & INVERSIÓ & & INVERSIÓ & & mes & mes \\
\hline C. d'adquisició & & & 120.000 & & & \\
\hline C.P.Parcial ai & 1,0 & para $10 \mathrm{Ha}, 40.000 \mathrm{~m}^{2}$ de techo, $40.000 €$ & 40.000 & & 12 & 1 \\
\hline C.P.Parcial ad & 0,3 & para $10 \mathrm{Ha}, 40.000 \mathrm{~m}^{2}$ de techo, $12.000 €$ & 12.000 & & 4 & 13 \\
\hline Beneficio Delimitación & & & & 26.365 .440 & & \\
\hline C.P.Reparc.ai & 1,5 & para $10 \mathrm{Ha}, 40.000 \mathrm{~m}^{2}$ de techo, $60.000 €$ & 60.000 & & 6 & 17 \\
\hline C.P.Reparc.ad & 0,5 & para $10 \mathrm{Ha}, 40.000 \mathrm{~m}^{2}$ de techo, $20.000 €$ & 20.000 & & 2 & 23 \\
\hline OGN Suelo & 0,5 & $15 \%$ de Coste Gestión Suelo & 19.800 & & 2 & 25 \\
\hline Beneficio Gestión. & & & & 5.691 .648 & & \\
\hline Indemnizacions & 50,0 & oscilan de 0 a 300 & 2.000 .000 & & 1 & 27 \\
\hline OGN Urb. & 7,9 & $12 \%$ de C.Urb. topografos, compañías, & 316.800 & & 2 & 28 \\
\hline C.Urbaniz & 66,0 & según ratio $\mathrm{BEC}$ & 2.640 .000 & & 10 & 30 \\
\hline \multirow[t]{2}{*}{ Beneficio Urbaniz } & & & & 9.900 .397 & & \\
\hline & & & 5.228 .600 & & & \\
\hline OGN Construcc. & 120,0 & $15 \%$ de C.Const. & 4.800 .000 & & 3 & 40 \\
\hline Coste Obras & 800,0 & según ratio $B E C$ & 32.000 .000 & & 18 & 43 \\
\hline Fin de Obra & 80,0 & $10 \%$ de imprevistos & 3.200 .000 & & 2 & 61 \\
\hline OGN Ventas & 90,0 & $3 \%$ de $\mathrm{V}$. venta & 3.600 .000 & & 3 & 63 \\
\hline Beneficio Promoción & & & & 29.485.714 & & \\
\hline
\end{tabular}

36

$\begin{array}{ll}\text { ai } & \text { aprovació inicial } \\ \text { ad } & \text { aprovació definitiva } \\ \text { ONG } & \text { altres despessas necessaries }\end{array}$


Aplicant la metodologia residual, i aplicant els arts. 24 i 25 de la nova llei de sòl, obtindrem els resultats següents

QUADRE 3

\begin{tabular}{|c|c|c|c|c|c|}
\hline & V.Creat & V.Llei $8 / 2007$ & V.Creat & V.Llei $8 / 2007$ & \\
\hline Valor Inicial & 498 & 3 & 19.937 .565 & 120.000 & \\
\hline Valor Delimitat & 676 & 5 & 27.048 .013 & 196.260 & \\
\hline Valor Gestionat & 820 & 69 & 32.780 .963 & 2.766 .714 & \\
\hline Valor Urbanitzat & 1.173 & 1.173 & 46.914 .286 & 46.914 .286 & \\
\hline V.Venta & 3.000 & valor de mercado sobre $\mathrm{m}^{2}$ techo $(\mathrm{SC}+\mathrm{ppz}$ & 120.000 .000 & 30 & 66 \\
\hline
\end{tabular}

Essent els valors del flux de caixa durant els tres períodes -delimitació, reparcel-lació i urbanització- el següent:

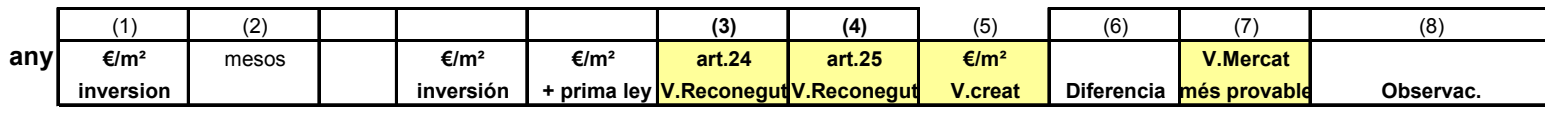

\begin{tabular}{|c|c|c|c|c|c|c|c|c|c|c|}
\hline 3.333 & 39 & & 3.333 & 4.100 & 124.100 & 124.100 & 19.937 .565 & 19.813 .465 & 3.021 .204 & 15 \\
\hline 3.333 & 38 & & 6.667 & 8.200 & 128.200 & 128.200 & 20.321 .322 & 20.193 .122 & 3.124 .017 & 14 \\
\hline 3.333 & 37 & & 10.000 & 12.300 & 132.300 & 132.300 & 20.712 .465 & 20.580 .165 & 3.230 .327 & 13 \\
\hline 3.333 & 36 & & 13.333 & 16.400 & 136.400 & 136.400 & 21.111 .137 & 20.974 .737 & 3.340 .254 & 12 \\
\hline 3.333 & 35 & & 16.667 & 20.500 & 140.500 & 140.500 & 21.517 .482 & 21.376 .982 & 3.453 .920 & 11 \\
\hline 3.333 & 34 & & 20.000 & 24.600 & 144.600 & 144.600 & 21.931 .649 & 21.787 .049 & 3.571 .452 & 10 \\
\hline 3.333 & 33 & 17 & 23.333 & 28.700 & 148.700 & 148.700 & 22.353 .787 & 22.205 .087 & 3.692 .982 & 9 \\
\hline 3.333 & 32 & & 26.667 & 32.800 & 152.800 & 152.800 & 22.784 .050 & 22.631 .250 & 3.818 .645 & 8 \\
\hline 3.333 & 31 & & 30.000 & 36.900 & 156.900 & 156.900 & 23.222 .595 & 23.065 .695 & 3.948 .583 & 7 \\
\hline 3.333 & 30 & & 33.333 & 41.000 & 161.000 & 161.000 & 23.669 .581 & 23.508 .581 & 4.082 .941 & 6 \\
\hline 3.333 & 29 & & 36.667 & 45.100 & 165.100 & 165.100 & 24.125 .170 & 23.960 .070 & 4.221 .868 & 5 \\
\hline 3.333 & 28 & & 40.000 & 49.200 & 169.200 & 169.200 & 24.589 .528 & 24.420 .328 & 4.365 .520 & 4 \\
\hline 3.000 & 27 & & 43.000 & 52.890 & 172.890 & 172.890 & 25.062 .823 & 24.889 .933 & 4.514 .059 & 3 \\
\hline 3.000 & 26 & & 46.000 & 56.580 & 176.580 & 176.580 & 25.545 .025 & 25.368 .445 & 4.667 .337 & 2 \\
\hline 3.000 & 25 & & 49.000 & 60.270 & 180.270 & 180.270 & 26.036 .505 & 25.856 .235 & 4.825 .818 & 1 \\
\hline 3.000 & 24 & & 52.000 & 63.960 & 183.960 & 183.960 & 26.537 .440 & 26.353 .480 & 4.989 .679 & P.P.a.d.= Sòl Delimitat \\
\hline 10.000 & 23 & & 62.000 & 76.260 & 4.679 .429 & 196.260 & 27.048 .013 & 26.851 .753 & 16.994 .979 & \\
\hline 10.000 & 22 & & 72.000 & 88.560 & 4.679 .429 & 208.560 & 27.573 .019 & 27.364 .459 & 17.569 .171 & \\
\hline 10.000 & 21 & 18 & 82.000 & 100.860 & 4.679 .429 & 220.860 & 28.108 .213 & 27.887 .353 & 18.162 .759 & \\
\hline 10.000 & 20 & & 92.000 & 113.160 & 4.679 .429 & 233.160 & 28.653 .795 & 28.420 .635 & 18.776 .398 & \\
\hline 10.000 & 19 & & 102.000 & 125.460 & 4.679 .429 & 245.460 & 29.209 .964 & 28.964 .504 & 19.410 .766 & \\
\hline 10.000 & 18 & & 112.000 & 137.760 & 4.679 .429 & 257.760 & 29.776 .927 & 29.519 .167 & 20.066 .562 & \\
\hline 10.000 & 17 & & 122.000 & 150.060 & 4.679 .429 & 270.060 & 30.354 .893 & 30.084 .833 & 20.744 .511 & \\
\hline 10.000 & 16 & & 132.000 & 162.360 & 4.679 .429 & 282.360 & 30.944 .076 & 30.661 .716 & 21.445 .360 & \\
\hline 9.900 & 15 & & 141.900 & 174.537 & 4.679 .429 & 294.537 & 31.544 .692 & 31.250 .155 & 22.169 .882 & \\
\hline 9.900 & 14 & & 151.800 & 186.714 & 4.679 .429 & 306.714 & 32.156 .888 & 31.850 .174 & 22.918 .779 & P.R.a.d.= Sòl Gestionat \\
\hline 2.000 .000 & 13 & & 2.151 .800 & 2.646 .714 & 4.679 .429 & 2.766 .714 & 32.780 .963 & 30.014 .249 & 32.780 .963 & \\
\hline 158.400 & 12 & & 2.310 .200 & 2.841 .546 & 4.679 .429 & 2.961 .546 & 35.001 .795 & 32.040 .249 & 35.001 .795 & \\
\hline 158.400 & 11 & & 2.468 .600 & 3.036 .378 & 4.679 .429 & 3.156 .378 & 35.801 .208 & 32.644 .830 & 35.801 .208 & \\
\hline 264.000 & 10 & & 2.732 .600 & 3.361 .098 & 4.679 .429 & 4.679 .429 & 36.618 .408 & 31.938 .979 & 36.618 .408 & \\
\hline 264.000 & 8 & & 3.260 .600 & 4.010 .538 & 14.038 .286 & 14.038 .286 & 38.489 .164 & 24.450 .879 & 38.489 .164 & \\
\hline 264.000 & 7 & & 3.524 .600 & 4.335 .258 & 18.717 .714 & 18.717 .714 & 39.458 .020 & 20.740 .306 & 39.458 .020 & \\
\hline 264.000 & 6 & & 3.788 .600 & 4.659 .978 & 23.397 .143 & 23.397 .143 & 40.449 .876 & 17.052 .733 & 40.449 .876 & \\
\hline 264.000 & 5 & & 4.052 .600 & 4.984 .698 & 28.076 .571 & 28.076 .571 & 41.465 .257 & 13.388 .686 & 41.465 .257 & \\
\hline 264.000 & 4 & & 4.316 .600 & 5.309 .418 & 32.756 .000 & 32.756 .000 & 42.504 .702 & 9.748 .702 & 42.504 .702 & \\
\hline 264.000 & 3 & & 4.580 .600 & 5.634 .138 & 37.435 .429 & 37.435 .429 & 43.568 .759 & 6.133 .330 & 43.568 .759 & \\
\hline 264.000 & 2 & & 4.844 .600 & 5.958 .858 & 42.114 .857 & 42.114 .857 & 44.657 .990 & 2.543 .133 & 44.657 .990 & \\
\hline 264.000 & 1 & & 5.108 .600 & 6.283 .578 & 46.794 .286 & 46.794 .286 & 45.772 .970 & -1.021 .315 & 45.772 .970 & \\
\hline V ESTATIC & 0 & & 46.914 .286 & & 46.914 .286 & 46.914 .286 & 46.914 .286 & 0 & 46.914 .286 & = Sòl Urbanitzat \\
\hline
\end{tabular}


sent
(1) costes necesarios para la transformación del suelo rural al suelo urbanizado
(2) plazos (en meses) en los que se presume se realizarán las operaciones
(3) valor reconocido según los criterios de la Ley de Suelo 8/07, art.24
(4) valor reconocido según los criterios de la Ley de Suelo 8/07, art.25
(5) valor creado, por aplicación del m.residual, valor máximo según el \% de $\mathrm{B}^{\circ}$
(6) diferencia entre el valor creado máximo y el valor reconocido por la Ley del Suelo
(7) hipótesis emulada por metodología mini-Delphi del valor más provable
(8) costes necesarios para la transformación del suelo rural al suelo urbanizado

ANNEX 2 (de com fer canvis en el benestar d'una societat)

Criteris de decisió social: Pareto, Kaldor-Hicks i Rawls 37

El criteri de Pareto, que rep el seu nom de l'economista italià Vilfredo Pareto

"..defineix simplement un estat (o situació) com eficient (o òptim) si en aquest estat no és possible millorar la situació de ningú sense empitjorar la situació d'alguna altra persona. Diem llavors que aquesta situació és eficient (o òptima), o que constitueix un òptim de Pareto" (Casahuga, 1985, pàg. 16).

Aquesta definició equival a afirmar que una situació o estat $S$ (ampliar el càmping) és superior (és preferit) a altra situació $R$ (no ampliar el càmping), "si almenys un individu es troba en $S$ en una posició superior al seu entendre i cap altre individu es troba en $S$ en una situació pitjor que en"R.

Pot observar-se que des d'aquesta perspectiva, la bondat d'una situació social determinada depèn de si existeix consens referent a això, és a dir si totes les persones afectades la consideren com bona.

Igualment, podem qualificar els canvis de situació com de canvi superior pareto, si amb el canvi, ningú perd, i almenys un guanya.. Gens ens informa, no obstant això, sobre la distribució dels recursos en el nou estat, ja que poden seguir tots pobres menys un que s'enriqueix 0 poden augmentar tots la seva riquesa per igual. La representació d'una economia de dos individus $(A$ i B) pot ajudar a entendre el criteri de Pareto

\footnotetext{
${ }^{37}$ Tesis Doctoral Dr. ALEGRET BURGUÉS, Alberto (Desembre de 2001) UPC, , pàg.63-66
} 


\section{Utilitats de dos individus (Pareto)}

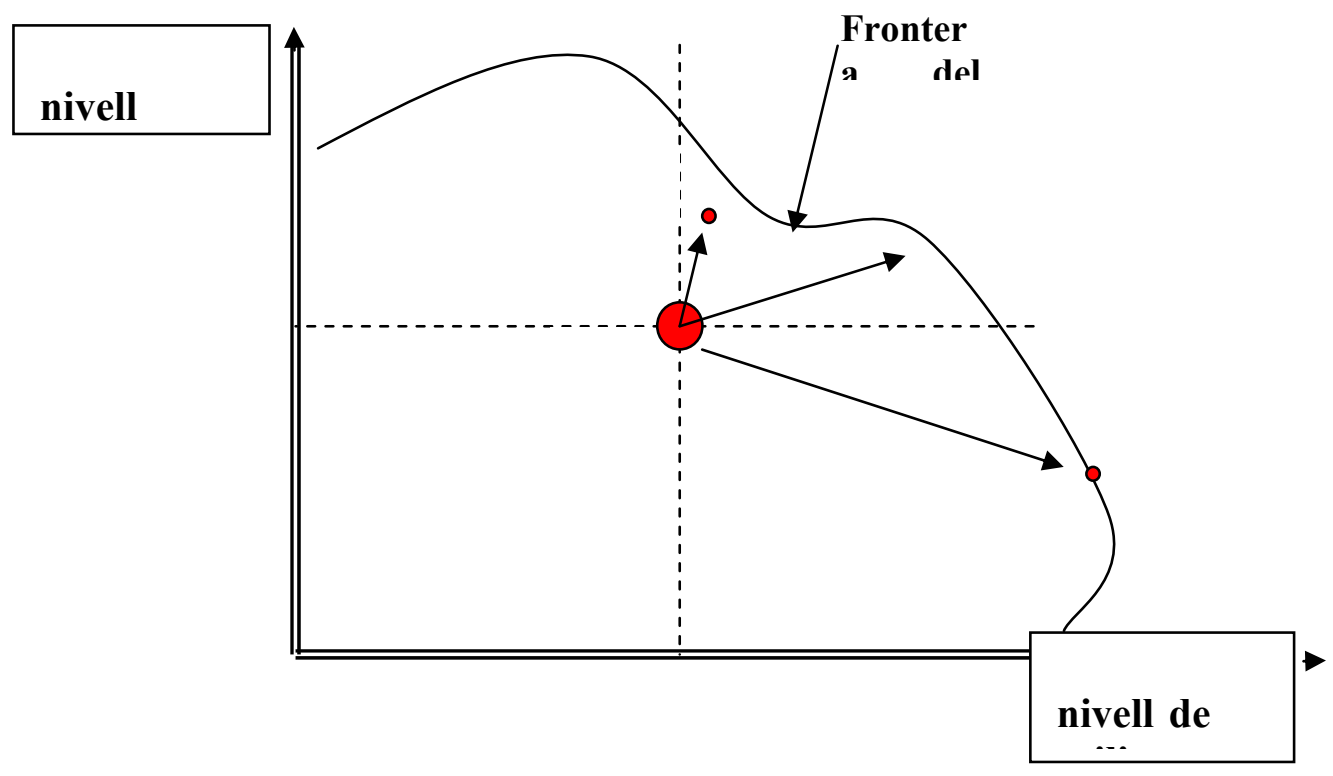

S. R. i. Z és la relació entre el nivell de utilitat dels individus A i B

Podem variar les relacions d'utilitat dels individus $A$ i B. Si passem d'una situació $S$ a altra situada en qualsevol punt del quadrant l, la utilitat de $A$ i de $B$ augmenten (canvi superior pareto). Si passem al quadrant III, la utilitat de $A$ i de B disminueixen (canvi inferior pareto). Si passem als quadrants II o IV, algú millorarà, però un altre empitjorarà.

Amb aquest criteri representarem la frontera de benestar, (o corba de possibilitats de la utilitat) com el lloc geomètric del màxim nivell de benestar que pot gaudir un individu, donats els nivells de benestar gaudits pels altres i les possibilitats tècniques d'aquesta societat.

Resulta necessari, no obstant això, completar el criteri de Pareto amb l'anàlisi dels canvis en els quals "necessàriament" algun individu perdrà (per exemple en la votació al parlament, en l'expropiació urbanística $i$ creació de sòl urbà). A tal final els economistes neoparetians Nicholas Kaldor (en 1939) i John Hicks (en 1940), van formular el que es coneix com el Criteri de Compensació (Pascual, 1999): 


\section{Utilitat de dos individus A i B (Kaldor-Hicks)}

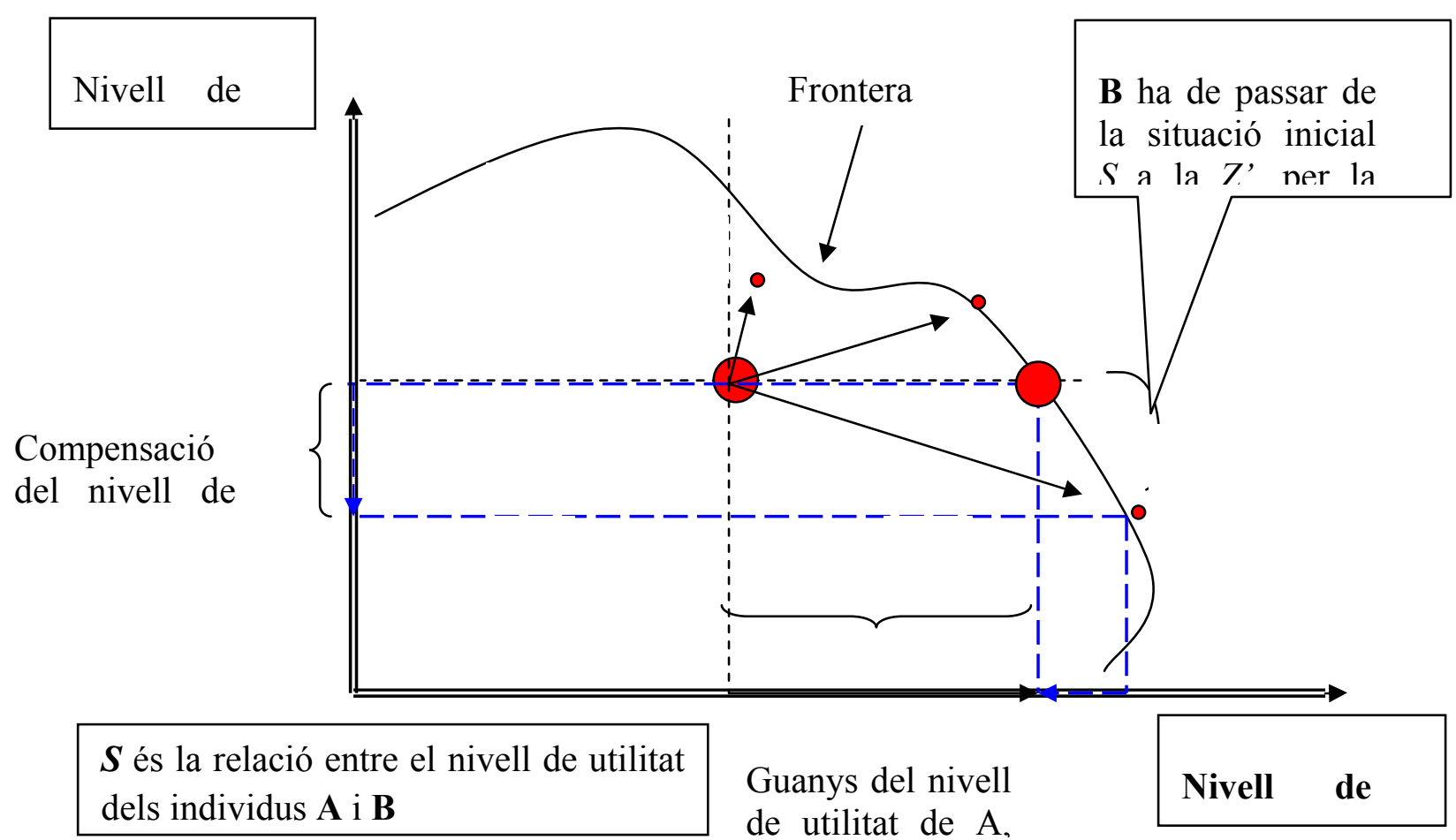

- En el sentit de Kaldor, davant dues alternatives, S i Z, incomparables en el sentit pareto, acceptis el pas de $S$ a $Z$ si els quals guanyen amb el canvi són capaços de compensar als perdedors i encara així seguir guanyant.

- En el sentit de Hicks, davant dues alternatives, S i Z, incomparables en el sentit pareto, acceptils el pas de $S$ a Z si els quals perden amb el canvi no són capaços de subornar als guanyadors perquè no portin a terme la reforma.

Sembla clar que si el pas a la situació Z (Z' final) compleix el criteri de Kaldor-Hicks, la nova situació conté un major benestar per a repartir que la primitiva: els quals guanyen poden compensar als quals perden (que se suposen reben la compensació per a quedar-se com estaven o millor) $i$ seguir no obstant això millorant el seu nivell inicial

Aquest és la base de l'Institut Reparcel/latori (Roca 1986), entès com aquell sistema en el qual s'establirà la justa distribució de càrregues $i$ beneficis que haurien de suportar els participants en un projecte de reparcel/lació o compensació.

A més del criteri de Pareto i dels criteris de compensació de Kaldor i Hicks, Rawls va criticar que cap dels anteriors recollís el concepte de justícia social, de manera que tant per a avaluar situacions o punts com per a determinar el desig d'un canvi, Pareto fixava tota l'atenció en l'eficiència, prescindint totalment del vessant distributiu, característica que s'accentuava en els criteris neoparetians (Kaldor i Hicks). En el pol oposat, Rawls situa en primer lloc la distribució del benestar, en qualsevol cas i de forma inequívoca. El benestar no es definiria en funció de la 
utilitat sinó en termes de béns primaris, com renda, riquesa, poder, drets, oportunitats $i$ llibertats.

Definició: El nivell de benestar en una societat s'identifica amb el de l'individu amb un benestar més baix, segons el PR.

Definició: En un òptim en el sentit de Rawls, no és possible disminuir la desigualtat sense empitjorar el benestar del ciutadà menys afavorit

Definició: Un canvi serà socialment desitjable seguint el PR, si i només si millora a l'individu pitjor situat.

Definició. Dues situacions són socialment indiferents segons el PR si proporcionen el mateix nivell de benestar social (és a dir, si no canvia el benestar de la persona més desfavorida)

L'aplicació reiterada del PR comportaria un benestar igual per a tots els ciutadans, sota condicions ideals; és a dir, si contra el que és habitual no existís conflicte algun entre eficiència i distribució."

\section{Bibliografia}

AZQUETA OYARZUN, Diego (1994). "Valoración Económica de la Calidad Ambiental", Mc. Graw Hill, Madrid.

ROCA CLADERA, Josep (1986). "Manual de Valoraciones Inmobiliarias". Ariel, Barcelona

ALEGRET I BURGUÉS, Alberto (2001).Tesi doctoral "La externalización de los valores inmobiliarios: el caso de la Sagrada Familia", Universitat Politècnica de Catalunya, Barcelona.

CASAHUGA, Antoni (1985). "Fundamentos Normativos de la Acción y Organización Social", Ariel, Barcelona.

LEY 8/2007 de Suelo.

Ordre ministerial ECO/805/2003 de 27 de marzo de 2003, sobre normas de valoración de bienes inmuebles y de determinados derechos para ciertas finalidades financieras.

JAVIER GARCÍA-BELLIDO GARCÍA DE DIEGO (2005). Ciudad y Territorio: Estudios Territoriales, ISSN 1133-4762, Nº 143, 2005, págs. 5-20

MORO, Tomás (1989). “Utopía (1518)". Traducida por Andrés Vázquez de Prada, Rialp, Madrid.

PASQUAL, Joan (1999). "La Evaluación de Políticas y Proyectos: Criterios de valoración económicos y sociales", pàg. 212 i sgt. Icària .UAB, Barcelona.

VACO a ALEGRET BURGUÉS, Albert (2001). Tesis Doctoral "Les Externalitats Immobiliàries: el cas de la Sagrada Família", pàg. 125 i sgt. Tesis Doctoral, Universitat Politècnica de Catalunya, Barcelona. 
CABRÉ I PUIG, Esteve (2005). Tesis Doctoral "Límits al mètode de Comparança", pàg. 44,45,138., Universitat Politècnica de Catalunya, Barcelona

Centre d'Estudis Immobiliari (2006), nota tècnica Tm010, de setembre de 2006.

Centre d'Estudis Immobiliari (2006), nota tècnica Tm017, d'octubre de 2006. 